\title{
THE ROLE OF INTERNATIONAL LAW WITHIN NATIONAL LEGISLATION ON TOBACCO CONTROL
}

Luís Renato Vedovato

Professor at the Master Law Program of Universidade Nove de Julho. Professor Doctor at UNICAMP.

lrvedovato@gmail.com

Abstract: The present article, taking into account advances in international rights and the need for domestic implementation of Framework Convention on Tobacco Control (FCTC) standards, has the objective of analyzing the competence to bring domestic and international regulations to fruition, with the purpose of creating coordinated public policies for tobacco control. So, it is possible to argue that the FCTC, by means of its guidelines, laid down at the Conferences of the Parties (COPs) and which are binding to all members states of the convention, paves the way for international regulation. Domestically, such regulation has to observe DOP guidelines, there being leeway for organizations like Brazil's ANVISA to bring those guidelines into action, such as the one related to FTCT articles 9 and 10, which limit the use of flavour additives in tobacco products, as a way of implementing international standards within the country. There is also no conflict between free enterprise and tobacco control given that, as stated by the Constitutional Court of Colombia in a process involving the constitutionality of restrictions to tobacco advertising, this is a market that should not be stimulated, but rather merely tolerated.

Keywords: Tobacco Control - Administrative Law - International Law Regulation

\section{INTRODUCTION}

There have been advances in International $\mathrm{Law}^{1}$ and, as a

1 Cf. CONFORTI, Benedetto. Diritto Internazionale. $8^{\text {a }}$. Ed. Napoli: EditorialeScientifica, 2010, p. 3: "In una prima approssimazioneildirittoInternazionalepuòesseredefinito come ildiritto (o 
consequence, it has gained ground in areas which were previously clearly intended for domestic standards. This is what can be empirically observed when any specific field of the law is analyzed, which will, inevitably, lean on international standards, as international law is experiencing constant expansion though with variable intensity, a fact that is consubstantiated in the differences concerning the implementation of standards. Such expansion, indeed, isn't accompanied by homogeneity with regards to the enforcement of International Law. In other words, though it can be observed that the various aspects concerning an individual's life and the role of the state are experiencing international standardization, the imperative of these provisions is not uniform, achieving greater effectiveness in areas linked to international trade and to jus cogens standards, whilst presenting a significant decrease in areas such as environmental protection and certain aspects of human rights.

According to $\mathrm{Shaw}^{2}$, as technology advances, in particular with regards to communication, the concept of sovereignty has been deeply altered due to the interdependence amongst states, which, in combination with "the tight organization of business corporations and contemporary politics at an international level", leads to all actions by the state, even those of a domestic nature, having repercussions in international relations and the internal decisions made by other states.

Therefore, Administrative Law was not rendered immune to International Law. In fact, a great number of international treaties require subsequent regulation, achieved through the Conference of the Parties, in a clear exercise of regulatory power, which allows for the creation of standards binding the nations involved ${ }^{3}$. Law, therefore, has to be altered to face the changes in reality, as made explicit by José Eduardo Faria $^{4}$, since the advent of the transnationalization of markets for inputs, production, capital, finance and consumption - which in just over a decade, has radically transformed the structures of political domination and appropriation of resources, it has subverted the notions of time and space, toppled geographical barriers, reduced legal and bureaucratic boundaries between nations, revolutionized production systems, structurally modified labour relations, turned investments in science, technology and information into privileged factors of productivity and competitiveness, created new and autonomous forms of power

ordinamento) della 'comunitàdegliStati'”.

2 SHAW, Malcolm N. Direito Internacional. São Paulo: Martins Fontes, 2011, p. 101.

3 On International Administrative Law, STEWART, R. B.; SANCHEZ BADIN, M. R. The World Trade Organization:Multiple Dimensions of Global Administrative Law.International Journal of Constitutional Law, v. 9, n. 3-4, p. 556-586. doi:10.1093/icon/mor051, 2011, accessed on April 6th 2012.

4 Cf. FARIA, J. E. C. O. O direito na economia globalizada. $1^{\text {a }}$ Ed. $4^{\text {a }}$ Tiragem. São Paulo: Malheiros, 2004, p. 13. 
and influence and, lastly, it multiplied the flow of ideas, knowledge, goods, services, cultural values and social problems exponentially and in a planetary-scale - legal thinking seems to be in a situation analogous to that in which it found itself during the economic thinking of the tumultuous late $20 \mathrm{~s}$, that is: faced with the challenge of finding alternatives to the paradigmatic exhaustion of its main theoretical and analytical models, such being the intensity of the impact generated by all these transformations within their conceptual schema, in their epistemological presuppositions, in their methods and procedures.

With the development of International Organizations and International Treaties, especially those that require further regulation, administrative law begins to surpass the boundaries of the state and to be influenced by international law to the same extent.

With regards to tobacco control - a field which received international regulation through the Framework Convention on Tobacco Control, created under the auspices of the World Health Organization-, administrative law will be instrumental in helping to define the legal nature of the guidelines and for the understanding of the competence of domestic regulatory agencies.

Therefore, what is currently being observed in the construction of international standards, is the division of the regulatory competence between domestic and international authorities, making possible the existence within the international stage of a growing interdependence and increasingly relevant ${ }^{5}$, which is also identified within public health, further amplifying the relevance of the World Health Organization and the Conference of Parties of the Framework Convention on Tobacco Control' ${ }^{6}$.

The present article, taking into account advances in international human rights and the need for domestic implementation of Framework Convention on Tobacco Control (FCTC) policies, has the objective of analyzing the competence to bring domestic and international regulations to fruition, with the purpose of creating coordinated public policies for tobacco control,tobacco sales, consumption, marketing and

5 STEWART, R. B.; SANCHEZ BADIN, M. R. The World Trade Organization:Multiple Dimensions of Global Administrative Law.International Journal of Constitutional Law, v. 9, n. 3-4, p. 556-586. doi:10.1093/icon/mor051, 2011, accessed on April 6 th 2012.

6 Cf.TAYLOR, ALLYN L., A. L.; ROEMER, RUTH, R.; LARIVIERE, JEAN, J. Origins of the WHO Framework Convention on Tobacco Control. SSRN eLibrary.from http://papers. ssrn.com/sol3/papers.cfm?abstract_id=818984, 2005, acessed on April 6th 2012: The growing number of public health concerns that are bypassing or spilling over national boundaries has ushered in a new era of global public health policy.Although there is a long history of multilateral cooperation in some limited areas of public health policy, particularly infectious diseases, public health has traditionally been viewed as being almost exclusively a national concern. However, with global integration has come a paradigm shift in which public health is now being recognized not only as a topic of global concern, but also as a global public "good". 
other factors related to this worldwide epidemy.

Ergo, the construction of standards, both at a domestic as at an international level, bears importance to the increase in tobacco control, and as such, a dialogue among those in charge of enforcing the law ${ }^{7}$ should initiated, which would enable a comparison between international and domestic provisions. The Framework Convention on Tobacco Control (FCTC) is an important element in building international standards on tobacco, restricting tobacco consumption, directly and indirectly.

To that end, we will conduct an incursion on International Law and tobacco control, focusing on the construction of the FCTC. The binding strength of the guidelines will also be discussed, exploring the legislative competence of the domestic regulatory agencies and the construction of global administrative law and how tobacco control is rooted on it.

The apparent conflict between the right of free enterprise, engraved in the Federal Constitution(in its article 170 and in FCTCarticle 5 , numeral 3, which prevents the participation of the tobacco industry in the construction of public domestic control policies ${ }^{8}$ ), will be given special attention at the end, before completion.

The selection of tobacco control by the World Health Organization (WHO) as the object of the first International Convention it presided, has its motivation based on the tobacco epidemic facing the globe. After a lengthy negotiation, the FCTC, arrived at its text and it was presented for signing between June 16th and 22nd, $2003^{9}$.

\section{INTERNATIONAL LAW AND TOBACCO CONTROL - THE FRAMEWORK CONVENTION ON TOBACCO CONTROL}

The need for the internationalization of tobacco control is not a recent discussion. As early as 1998, during the Seminar on Tobacco Industry Disclosures, at WHO headquarters in Geneva, Gro Harlem Brundtland declared that tobacco control cannot be left in the hands of individual efforts by domestic players; but rather, according to Brundtland,

7 CARVALHO RAMOS, André. O Diálogo das Cortes: O Supremo Tribunal Federal e a Corte Interamericana de Direitos Humanos. In: AMARAL JÚNIOR, Alberto do; JUBILUT, Liliana Lyra. (Org.). O STF e o Direito Internacional dos Direitos Humanos. São Paulo: Quartier Latin, 2009 , p. 817.

8 On the interference of the industry in the construction of public policies, cf.GILMORE, A.; NOLTE, E.; MCKEE, M.; COLLIN, J. Continuing influence of tobacco industry in Germany. The Lancet, v. 360, n. 9341, p. 1255. doi: 10.1016/S0140-6736(02)11262-1, 2002.

9 VEDOVATO, Luís Renato . A Convenção Quadro sobre Controle do Uso do Tabaco. In: Clarissa Menezes Homsi. (Org.). Controle do Tabaco e o Ordenamento Jurídico Brasileiro. $1^{\mathrm{a}}$ ed. Rio de Janeiro: LUMEN JURIS EDITORA, 2011, v. 1, p. 3-31. 
what is needed is for this issue to be conducted at an international level ${ }^{10}$. In pursuit of greater effectiveness, tobacco control advanced towards the creation of international standards ${ }^{11}$, in order to face the global epidemic that created interdependence among states, which join their efforts in the name of public health.The issue of tobacco has surpassed national borders to become a global concern. So much so that an International Treaty on Tobacco Control was celebrated in 2003, called the Framework Convention on Tobacco Use Control, of which Brazil became a definite signatory, through ratification on November 3rd, 2005, and which was published on January 2nd, 2006, under Presidential Decree. 5658.

The Framework Convention is a modality of international treaty in which state members proceed to structure comprehensive frameworks for standards ${ }^{12}$, and it should be emphasized that the doctrinal texts regarding the terminology of the treaties make explicit the lack of significance to the name given to the treaty, as it is its content that defines $i^{13}$. Therefore, what should guide the interpreterit is the content of the international text, rather than the conventional terminology.

The FCTC has more definitive ties (173) than signatures (168) because, despite the deadline for subscriptions having expired, there is room for the ratifications of those who have already signed, or further adhesion from those who have not yet signed, but who intend to follow international standards on tobacco control. In addition to this, the states that have signed the Convention have agreed to engage, in good faith, in ratifying, accepting or approving it, and to show the political commitment not to undermine the objectives defined therein.

The Convention became effective as of February 27th, 2005, as determined on article 36, 1st paragraph, of the Treaty. Under these terms, states are bound to abide by the provisions of the Treaty and its guidelines, created at the Conferences of the Parties, in accordance with article 5, numeral 4 , of the FCTC text.

The role of the guidelines is, then, to determine the implementation of healthy public policies required for controlling the use of tobacco ${ }^{14}$, which could stimulate the development of a global

10 Available in http://www.who.int/director-general/speeches/1998/english/19981020_tfi.html, accessed on April 6th 2012.

11 The long road towards the construction of the FCTC can be observed in YACH, D. From Framingham to the Framework Convention on Tobacco Control. Progress in Cardiovascular Diseases, v. 53, n. 1, p. 52-54. doi:10.1016/j.pcad.2010.05.001, 2010, accessed on April 6th 2012. 12 SOARES, Guido Fernando Silva. Curso de Direito Internacional Público. 2. ed. São Paulo: Editora Atlas, 2004, p. 63

13 REZEK, José Francisco. Direito Internacional Público - Curso Elementar. 13a .ed. São Paulo: Saraiva, 2011, p. 38.

14 With regards to the promotion of healthy public policies, especially within urban areas, 
uniformity in dealing with tobacco issues, in regards to local peculiarities. The combination of domestic and international standards is essential to make a full implementation of the Convention possible. To that end, it is necessary to count on both domestic and international involvement for the development of public policies and the reconfiguration of the legal system, including changes in its interpretation.

Seeking to implement FCTC standards, Conferences of the Parties (COP) were held, which, according to article 23 of the Convention, is the organ responsible for the coordination of actions for the execution of the WHO FCTC. All countries bound by the treaty are part of the COP, with meetings being held every two years.

Through article 23, numeral 5, of the FCTC, the COP will regularly review the implementation of the Convention, and make the necessarydecisions to promote an effective implementation of the Convention ${ }^{15}$. It should, therefore, promote and facilitate the exchange of information, guide the set up and periodic improvement of comparable methodologies for research and data collection that are relevant to the implementation of the Convention; promote, where applicable, the development, implementation and evaluation of strategies, plans and programs, as well as policies, legislation and other measures; reviewing the reports submitted by the Parties, adopting regular reports on the implementation of the Convention ${ }^{16}$; facilitate the mobilization of financial resources for theimplementation of the Convention; establish suchsubsidiary organs as needed in order to achieve the objectives of the Convention; requesting, when appropriate, services, cooperation and information from

it's worth checking the work of Sperandio and Ana Maria GirottiLauroLuiz Francisco Filho, whose work is focused on promoting health and urbanism, developed in conjunction with the Laboratory of Urban Research (LABINUR) of the FEC UNICAMP.

15 Cf. MEIRELLES, R. H. S. A ratificação da Convenção-Quadro para o Controle do Tabaco pelo Brasil: uma questão de saúde pública. JornalBrasileiro de Pneumologia, v. 32, n. 1, p. 0-0.doi: 10.1590/S1806-37132006000100002, 2006, accessed on April 6th 2012: "The text of the FCTC provides measures for reducing demand, such as, for example, an increase in prices and taxes, protection from exposure to tobacco smoke, the promotion of smoking cessation, a restriction or ban on tobacco advertising, promotion and sponsorship and measures to reduce the supply of tobacco, such as, for example, the control of illegal trade (smuggling), banning the sale of tobacco by-products to minors and support for economically viable alternative activities to tobacco crops". 16 Cf.TAYLOR, ALLYN L., A. L.; ROEMER, RUTH, R.; LARIVIERE, JEAN, J. ob. cit.:"The WHO FCTC is designed to strengthen national and international coordination to combat the tobacco epidemic.Formally negotiated by WHO member states over a period of 4 years, the treaty incorporates a variety of measures to encourage state parties to curb the growth of tobacco production and use, including some measures that constitute concrete obligations and other commitments that are framed as goals or recommendations.For example, the treaty requires that state parties implement restrictions on advertising, sponsorship, and promotion and implement strong packaging and labelling requirements. The treaty also calls on countries to establish clean indoor air controls and strengthen legislation to combat tobacco smuggling." 
UN organizations and agencies, and from other intergovernmental and non-governmental organizations and bodies, international and regional, competent and pertinent, as a means of strengthening the implementation of the Convention; in addition to considering further measures, where applicable, in order to achieve the objective of the Convention, in the light of the experience gained in its implementation ${ }^{17}$.

For Hammond and Assunta, the main objectives of the FCTC are encouraging states to implement comprehensive bans on tobacco advertising, promotion and sponsorship; making compulsive the warnings on packages of tobacco, aiming to cover at least $30 \%$ of the main visible areas and which may include pictures or pictograms; prohibit the use of misleading terms like "light" and "mild"; protect individuals from exposure to tobacco smoke; combat smuggling and illegal trade, adding information about the final destination on the package itself, in addition to raising taxes on tobacco ${ }^{18}$. The FCTC encourages countries to create more advanced controls than those set in its provisions, which indicates that it only sets forth the minimum standards required.

This is what can be observed in article2, numeral 1, which states that "Parties are encouraged to implement measures beyond those required by this Convention and its protocols, and nothing within these instruments shall prevent a Party from imposing stricter requirements, consistent with their domestic provisions and conforming to International Law"19.

It is therefore assumed, that domestic protection is more encompassing than the international. However, as FCTC helps by setting minimum standards, when compared with the domestic laws of a party state, it cannot be more advanced with regards to tobacco protection and control. In this way, it is subject to generating the international responsibility of the state in which the international protection is greater than the domestic.

Also, under conventional strength, guidelines and protocols (FCTC article 5, numeral 4), are part of international law aimed at tobacco control, which, however, possess an intrinsic component of international administrative law. Such acts can fit into fruits of the exercise of the Regulating Power $^{20}$ of public administration ${ }^{21}$. In this

17 Cf.HAMMOND, R.; ASSUNTA, M. ob. cit.

18 Cf.HAMMOND, R.; ASSUNTA, M. ob. cit..

19 Cf.HAMMOND, R.; ASSUNTA, M. ob. cit..

20 On the Regulatory Power, also called Normative Power, cf. COELHO, Paulo Magalhães da Costa. Manual de Direito Administrativo . 1a. ed. São Paulo: Saraiva, 2004, p. 67; cf. also, onthesamesubject, BANDEIRA DE MELLO, Celso Antonio. Curso de Direito Administrativo . $15^{\mathrm{a}}$. ed. São Paulo: Malheiros, 2003, p. 309; . ARAUJO, E. N. . Curso de Direito Administrativo. $3^{\text {a }}$. ed. São Paulo: Editora Saraiva, 2007, 466; DI PIETRO, Maria Sylvia Zanella. Direito Administrativo. $21^{\text {a }}$. ed. São Paulo: Editora Atlas, 2008, p. 82.

21 Cf. CARVALHO FILHO, José dos Santos. Manual de direito administrativo. $24^{\mathrm{a}}$ Ed. Rio de 
case, however, the structure of the Convention and the COP play the role of public administration, with the advantage that they can be regarded as the authentic interpretation of the FCTC.

The authentic interpretation is that which is made by the body from which the normative text originated. So, in this case, the authentic interpretation is processed through the development of guidelines.

Therefore, states are bound by guidelines and protocols, which arise from the Convention itself and serve to explain the international interpretation of the provisions, removing the risk of the domestic interpretation of international standards. As such, the guidelines play the role of making them explicit and of guiding the actions of the members of the Convention, which is commonplace within the domestic law of those states, bringing a binding force to the guidelines identical to that of the standards in the FCTC text ${ }^{22}$. Such guidelines were originatedfrom the COPs held so far,as determined by the Convention.

\section{THE GUIDELINES CREATED AT THE CONFERENCE OF THE PARTIES}

Following conventional prediction, with the objective of promoting the implementation of the provisions of the treaty, the FCTC allows for the creation of various instruments such as protocols and guidelines, making room for authentic interpretation of the provisions of the treaty to be made, in addition to detailing and taking actions for tobacco control further. At every COP, the Parties are called to report progress and any difficulties faced, which creates conditions for monitoring of States by the COP, helping ascertain in which areas lie the challenges for effective implementation of the FCTC.The reports presented by the member states also aid as educational tools for those involved.

The Secretariat of the Convention, the creation of which was determined in FCTC article 24, is established at the headquarters of the World Health Organization in Geneva. This provision also defines, in

Janeiro: Lumen JurisEditora, 2009, p. 51.

22 In addition to being an important reference to the works on Administrative Law, cf.VERDIER, P.-H. Transnational Regulatory Networks and Their Limits.Yale Journal of International Law, v. 34, p. 113-172, 2009, accessed on April 6th 2012: "Since the end of World War II, ambitious institutions and regimes have emerged to regulate international economic life. The General Agreement on Tariffs and Trade (GATT) provided multilateral legal guidelines for governing trade restraints; the World Trade Organization (WTO), as the new incarnation of the GATT's original institutions, has extended its jurisdiction to encompass intellectual property and services. The International Monetary Fund (IMF) initially wielded extensive authority over the international monetary system and, though its mission has been in flux since the 1970s, retains a leading role in the international financial system. Alongside these global regimes, numerous regional and bilateral treaties pursue greater trade liberalization and investment protection. Other treaty regimes control trade in specific goods such as nuclear materials, weapons, and cultural property." 
its numeral 3, the functions of the Secretariat, looking to divulge the decisions made by the $\mathrm{COP}^{23}$.

According to forecast of the Convention, the First Conference of the Parties (COP1) was held between 6 - 17 February, 2006, in Geneva, and ended with validation for 113 Parties. It defined the rules for its funding, by consensus, as well as determining the creation of the Secretariat, which is connected administratively to the Director General of $\mathrm{WHO}^{24}$.

The Second Conference of Parties (COP2) was held between June 30th - July 30th, 2007, in Bangkok, Thailand, by then with 146 Parties having joined. At this meeting, the guidelines for the implementation of the artigo $8^{\circ}$ da CQCT protection that comes from exposure to tobacco smoke and the adoption of 100\% smoke-free environments, having also created an Intergovernmental Negotiating Body (INB), in order to develop a protocol on the illicit market in tobacco products, as according to FCTC article 15, which presented significant advances in March 2012 ${ }^{25}$.

The Third Conference of the Parties (COP3) was held between 17 - 22 November 2008, in Durban, South Africa, in which were approved guidelines for the implementation of article5, numeral 3, important with regards to the influence of the industry in the development of public policies; art. 11, concerning the packaging and labelling of tobacco products; in addition to article 13, concerning tobacco advertising, promotion and sponsorship ${ }^{26}$.

The Fourth Conference of the Parties (COP 4) was held between 15 - 20 November, 2010, in Punta Del Este, Uruguay. During this meeting, the guidelines for the implementation of regulation of content and the dissemination of information on tobacco products, in a partial manner; of education, communication, training and raising public awareness; the measures for reduction of demand on related to tobacco dependence and tobacco cessation, respectively, relating to articles 9,

23 FCTC Art. 24, numeral 3: Secretariat functions shall be: (a) to make arrangements for sessions of the Conference of the Parties and anysubsidiary bodies and to provide them with services as required; (b) to transmit reports received by it pursuant to the Convention; (c) to provide support to the Parties, particularly developing country Parties and Parties with economies in transition, on request, in the compilation and communication of information required in accordance with the provisions of the Convention; (d) to prepare reports on its activities under the Convention under the guidance of the Conference of the Parties and submit them to the Conference of the Parties; (e) to ensure, under the guidance of the Conference of the Parties, the necessary coordination with the competent international and regional intergovernmental organizations and other bodies; (f) to enter, under the guidance of the Conference of the Parties, into such administrative or contractual arrangements as may be required for the effective discharge of its functions; and $(\mathrm{g})$ to perform other secretariat functions specified by the Convention and by any of its protocols and such other functions as may be determined by the Conference of the Parties. 24 Cf. http://www.who.int/fctc/cop/sessions/first session_cop/en/index.html $25 \mathrm{Cf}$. http://www.who.int/fctc/cop/sessions/second session cop/en/index.html 26 Cf.http://www.who.int/fctc/cop/sessions/third_session_cop/en/index.html 
10, 12 and 14, were all approved.

This meeting also determined the creation of a working group aimed at creating guidelines on prices and taxes (Article 6) and to continue the support work regarding economically viable alternative activities and the protection of the environment and people's health.It also established that the negotiations on the Protocol on Illicit Market are still to continue for one more session in 2012, as well as setting up a group of experts in the field of cross-border advertising ${ }^{27}$.

The Fifth Conference of the Parties (COP5) is scheduled to take place in November 2012, in South Korea ${ }^{28}$.

\section{INTERNATIONAL ADMINISTRATIVE LAW AND THE BINDING FORCE OF THE GUIDELINES}

Hard and complex negotiations in all meetings go to show that there are many obstacles to the fulfilment of the Convention. The symptoms of the emergence of supercapitalism, as outlined by Robert Reich $^{29}$, may result in new configurations and challenges for the creation of healthy public policies. As Reich points out, the new capitalism drives companies to seek control of the regulation process, drawing them ever nearer to the state's decision-making centres ${ }^{30}$. Hence, the importance of the creation of internal networks for implementation of the Convention ${ }^{31}$ is understood, but it also proves essential the implementation of the guidelines of FCTC article 5, numeral 3.

As the fruit of the Regulatory Power, with the advantage of also being an authentic interpretation of the Convention made by the individuals who created it, these guidelines gain an imperative binding stature.

What can then be observed is the international interpretation of international standards, which lessens the possibility of mistaken actions by states Parties.

There is a simple logic; the Convention, as the treaties in general ${ }^{32}$, is signed by the Executive Power and approved by the Legislature ${ }^{33}$, gaining

27 Cf.http://www.who.int/fctc/cop/sessions/fourth_session_cop/en/index.html

$28 \mathrm{Cf}$. http://www.who.int/fctc/cop/sessions/fifth_session_cop/en/index.html

29 REICH, Robert. Supercapitalismo. Rio de Janeiro: Ed. Campus, 2008, capítulo 4, p. 139.

30 Idem,p. 150.

31 The Rede de Municípios Potencialmente Saudáveis (Network ofPotentiallyHealthyCounties) isimportantwithinBrazil, headedby Ana Maria G. Sperandio. Availableat: <www. rededemunicipios.org.br>.

32 Cf. ACCIOLY, Hildebrando; NASCIMENTO E SILVA, Geraldo Eulálio do. Manual de Direito Internacional Público. 19ª ed. CASELLA, Paulo Borba, atualizador. São Paulo: Saraiva, 2011, p. 233. 33 Taking as a reference what happens in Brazil, whilst being important, however to highlight the fact that it follows a complex path with the participation of the Legislature by constitutional 
ground within the domestic legal system after the Presidential Decree ${ }^{34}$, which is not required internationally, a ground in which it will be binding for the parties, as well as all guidelines created at the Conferences.

In Brazilian law, the treaty will come into being after the Presidential Decree, which forms the basis of validity for the guidelines originated as an interpretation of its text and as a product of what can be called the Regulatory Power of International Administrative Law.

The disseminated dialogue, as advocated by Carvalho Ramos ${ }^{35}$, in the case of the guidelines, will be consolidated by public policies.

The fact that the guidelines resemble abstract judicial decisions, similar to those that occur in the concentrated control of the constitutionality of standards, cannot be discarded.

The COP would play the role of a "court" because it would act as a recognized interpreter, thus interpreting the FCTC and defining the standards to be applied by the parties.

Therefore, there is no way to remove the binding nature of the guidelines, which are a means of clarifying the conventional exegesis. The FCTC guidelines comprise the expressions of a network of transnational regulation, the so-called TRNs (Transnational Regulatory Network) ${ }^{36}$. The TRNs concern is focused on issues of international trade; however, it can be applied to public health as it is laden with interdependence and already structured in relation to tobacco, by international treaty. According to $\operatorname{Verdier}^{37}$ :

The emergence of several major cooperative initiatives among national regulators began engaging the attention of international law scholars in the 1990s. The Basel Committee had successfully adopted an international accord on bank capital adequacy in 1988, and efforts were underway to strengthen the rulemaking activity of IOSCO and the International Association of Insurance Supervisors (IAIS).Networks of environmental and antitrust regulators were also cited to illustrate an

order, as emphasized

34 In Brazil, for a treaty to become part of the Brazilian legal system, it is necessary for the act of the Executive Power to take place (by signature or the adoption of the text), in addition, the treaty is subject to internal approval by the Legislature, which is preceded by ratification, being finalized by presidential decree, as well defined in RE 466.343, adjudicated by the Supreme Court in 2008 . 35 Cf. CARVALHO RAMOS, André. O Diálogo das Cortes: O Supremo Tribunal Federal e a Corte Interamericana de Direitos Humanos. In: AMARAL JÚNIOR, Alberto do; JUBILUT, Liliana Lyra. (Org.). O STF e o Direito Internacional dos Direitos Humanos. São Paulo: Quartier Latin, 2009.

36 Cf.VERDIER, P. -H. works previously cited.

37 Cf.VERDIER, P. -H. works previously cited. 
emerging global trend toward soft law and informal regulatory cooperation.Early commentators expressed concern that these initiatives evidenced a shift toward disaggregated global governance by experts acting outside the constraints of domestic political structures and the normal foreign affairs process

The advances in international administrative law set the ground for more in-depth dialogue and make domestic regulations follow international directives ${ }^{38}$, rendering the guidelines binding and mandatory when setting domestic policy. The growth of this phenomenon is palpable within current law, as described by Stewart et $\mathrm{al}^{39}$, when dealing fundamentally with the World Trade Organization, in the following terms:

As exemplified by the WTO, we are witnessing the pervasive shift of authority from domestic governments to global regulatory bodies in response to deepening economic integration and other forms of interdependency. The growing density of regulation beyond the state enables us to identify a multifaceted global regulatory and administrative space populated by many distinct types of specialized global regulatory bodies, including not only formal international organizations like the WTO but also transnational networks of domestic regulatory officials, private standard setting bodies, and hybrid public-private entities.

Therefore, as they are standards proceeding from International Organizations, which define rules for the creation of guidelines for the parties they are applied by, it is possible to conclude that the binding comes from international administrative law, which adds to the fact that it is a form of authentic interpretation of the Convention.

\section{Domestic Regulation}

In order not to run the risk of the international treaty suffering from a peculiar internalization of its interpretation and application, which could lead to its distortion, as every state could end up giving

38 The executive agreements which are only materialized through the participation of the Executive Power of the State, can be seen as modalities of the exercise of the international regulatory power, cf. REZEK, José Francisco. Direito Internacional Público - Curso Elementar. $13^{\mathrm{a}}$. ed. São Paulo: Saraiva, 2011, p. 86.

39 STEWART, R. B.; SANCHEZ BADIN, M. R. ob. cit. 
the treaty a meaning it understood better, the international guidelines should be followed up by domestic actions, particularly in regards to the implementation of public policies, in a uniform manner by the parties. In this way, the guidelines would allow for all states to have a single interpretation of the conventional standards. Regulatory agencies ${ }^{40}$, in those countries where they exist, are the domestic vehicle for the implementation of international guidelines.

In other words, there is no need to pass the act to make concrete the international guideline on the domestic front, in the legislature.

The domestic administrative body may, therefore, in the exercise of its regulatory capacity ${ }^{41}$, create the rules necessary for more effective control of tobacco, which is strengthened by the domestic application of international standards and guidelines ${ }^{42}$, as the international guideline is just for making explicit the international interpretation of the text of the treaty.

Regulatory Agencies have autonomy and must act to achieve the fulfilment of their goals, as according to Carlos Ari Sundfeld ${ }^{43}$ :

\begin{abstract}
The agencies have been endowed with some 'independence', referred to in legislation as an important characteristic of several of them. 'Independence' is certainly an exaggerated expression. Within the legal world, we prefer to speak of autonomy. But ensuring independence is to make a rhetorical statement in order to emphasize the wish that the agency becomes an autonomous entity in relation to the Executive Power, for it to act impartially and not waver its orientation due to oscillations that, by virtue of the democratic system itself, are characteristic to this Power.
\end{abstract}

40 According to MOTTA, Paulo Roberto Ferreira, Regulatory Agencies make up the Brazilian option, though they are not pioneers in the domestic regulation of industries. Agênciasreguladoras. $1^{\mathrm{a}}$. ed. Barueri, SP: Manole, 2003, p. 12, who expresses it in the following manner: "Although, for some, these independent entities, amongst regulators, may seem like a new legal institution or an innovation within our positive law system, it is necessary to stress that entities with the same functions have already existed within Brazilian Law for much longer than one might imagine, and which perform, concurrently, legislative, administrative and jurisdictional functions".

41 On the normative capacity, refer to ROCHA, Jean-Paul. Regulação Econômica e Separação dos Poderes: a Delegação Legislativa na Tradição do Direito Público Brasileiro. Revista de Direito da Associação dos Procuradores do Novo Estado do Rio de Janeiro, Rio de Janeiro, v. XI, p. 69-87, 2002. 42 RIVERO, L. R.; PERSSON, J. L.; ROMINE, D. C. et al. Towards the world-wide ban of indoor cigarette smoking in public places.International Journal of Hygiene and Environmental Health. 1 v. 209, n. 1, p. 1-14. doi:10.1016/j.ijheh.2005.07.003, 2006, accessed on April 6th 2012. 43 SUNDFELD, Carlos Ari. Introdução às Agências Reguladoras. In SUNDFELD, Carlos Ari (Org.).Direito Administrativo Econômico. São Paulo: Malheiros, 2006, p. 23. 
In March 2012, through the exercise of this autonomy, the Brazilian National Agency of Sanitary Surveillance determined a ban on marketing cigarettes with additives aimed at altering the original flavour of the cigarette, the so-called flavour additives.

Such resolution is in line with international provisions and in line with discouraging tobacco consumption, as determined by the COP4 guideline, regulator of articles 9 and 10 of the FCTC. Such a ban, in fact, is aimed at averting the masking of the bad flavour of tobacco, preventing flavours from being used as an incentive for experimentation and maintenance of addiction.

The question that has been asked is whether ANVISA acted within its jurisdiction. Therefore, it is worth relating this to other products. If there was a way to make an alcoholic drink taste like milk or yogurt, whilst retaining its other characteristics, such as alcohol content and addictive potential, ANVISA has the power to prohibit that such product is marketed, as it may facilitate use of the product by young people. The law from which ANVISA was created, Law number 9.782, of January 26th, 1999, comes with its list of competences, and it should act as an independent administrative entity, having the prerogatives necessary for the adequate performance of its attributions assured, pursuant to article 4 of the Law. The ban on additives in alcoholic beverages would be a natural response, as it would mask the flavour that can be an obstacle in reaching a wider audience, especially among younger people.

As for tobacco, something of the kind was done, i.e., consumption must be controlled and the product should not be made attractive to young people. Moreover, Brazil is committed to fulfilling the treaty and therefore is bound by its guidelines. In this case, the guideline was approved at the COP4 in order to give greater effectiveness to articles 9 and 10 of the FCTC.

Thus, the ban is entirely feasible, as it is in line with the aforementioned guideline and the purposes for which the Agency was created, which also has within its competence, according to Article 7, among other topics: coordinating the National System of Health Surveillance; to foster and conduct studies and research within its powers; to set standards, to propose, implement and monitor policies, guidelines and health surveillance actions; to set norms and standards on limits of contaminating substances, toxic waste, disinfectants, heavy metals and others that constitute a health risk; to intervene, temporarily, in the administration of manufacturing entities that are funded, subsidized or maintained with public funds, as well as the service providers and exclusive or strategic producers for the supply of the domestic market; to administer and collect the health surveillance tax; to interdict, as a measure of health surveillance, places of manufacture, control, import, storage, distribution and sale of products and services relating to health, 
in the case of a violation of pertinent legislation or of imminent risk to health; to coordinate health surveillance activities conducted by all the laboratories that comprise the official network of laboratories for quality control in health; to coordinate and perform quality control of goods and tobacco-related products, through analysis under health laws, or through special programs for monitoring quality in health; to control, supervise and monitor, through the perspective of health legislation, the propaganda and advertising of products subject to the regime of health surveillance.

Furthermore, it is worth noting that the responsibility of regulating, controlling and monitoring products and services that involve a risk to public health falls upon ANVISA, pursuant to article 8 of Law $9.782 / 99$. There is an express reference to tobacco as a product that involves health risk, in article $8^{\circ}, \S 1^{\circ}$, inc. X, and, as such, determining its competence. Cigarettes, cigars and any other smoking products derived or not from tobacco, are considered goods and products subject to health inspection and enforcement by the Agency.

In this capacity, ANVISA issued regulations on the subject, exercising its regulatory powers, which, according to Carlos Ari Sundfeld ${ }^{44}$, it maintains full compatibility with the law in the following terms:

Is it true, as some fear, that the regulatory agency is perforce a usurping force of the legislative function? No. In modern times, the Legislature does what it always does: it edits laws, often with a high degree of abstraction and generality. Except that, according to the new standards of society, these norms are not quite enough, more direct and precise rules are needed for dealing with specifics, performing the planning of sectors, facilitating the intervention of the state in ensuring compliance and the fulfilment of these values : the protection of the environment and the consumer, the pursuit of national development, the expansion of national telecommunications, control over economic power - in short, all of those who nowadays we've come to consider fundamental and the prosecution of which we demand from the state.

The state then created ANVISA and gave it the task of controlling tobacco use, which involves both health and control of economic power, in view of the performance of companies operating in the sector.

Therefore, ANVISA actions ${ }^{45}$ serve to make the FCTC effective

44 SUNDFELD, Carlos Ari. Introdução às Agências Reguladoras. In SUNDFELD, Carlos Ari (Org.). DireitoAdministrativoEconômico. São Paulo:Malheiros, 2006, p. 27.

45 It is also worth noting that regulation is a duty of the Agency, as it should accompany the 
and, through following conventional provision, to advance tobacco control, as according to FCTC article 2, numeral 1, which states that with "a view to better protect human health, the Parties are encouraged to implement measures that go beyond those required by this Convention and its protocols, and nothing within those instruments will prevent a Party from imposing stricter requirements, consistent with their domestic provisions and in accordance to international law.

\section{THE INFLUENCE OF THE TOBACCO INDUSTRY AND FREE ENTERPRISE}

According to article 5, numeral 3, of the Framework Convention on Tobacco Control, in defining and implementing their public health policies related to tobacco control, the Parties shall act to protect these policies against commercial and other vested interests guaranteed for the tobacco industry, in compliance with national legislation. At this point, the conflict between free initiative (article 170 of the Federal Constitution) and the right to health (article196 of the FC), emerges.

In Article 170 of the Federal Constitution, free enterprise is defined as one of the fundamentals of the Brazilian economic order.It is worth noting that the provisions are not contradictory and can be interpreted in conjunction, despite there being constant debates on the violation of free enterprise by state interference in the economy.In other words, in actions brought about in Uruguay regarding health warnings, and in Australia on the use of the whole packaging for health warnings, the tobacco industry has argued that state interference undermines free enterprise as it cannot act within the market in order to promote and sell its product.

First, however, it is highlighted that much progress has been made in tobacco control and, currently, it has an essentially economic significance within society, with the period where it enjoyed cultural and religious ties having already been overcome, as pointed out by Rivero et $\mathrm{al}^{46}$, in the following terms:

In the past, certain religions have used smoking as part of rituals and ceremonies, but such practices have fallen into disuse. Muslims around the world stop smoking during the month offasting of Ramadan.Native Americans have a cultural basis for using tobacco.Historically, some tribes have used tobacco as a "life affirming and sacramental substance that plays a significant role in

principle of legality, it must regulate and follow the FCTC provision, which was incorporated into the Brazilian legal system, cf. SUNDFELD, Carlos Ari ; CÂMARA, JacinthoArruda . Dever regulamentar nas sanções regulatórias. Revista de Direito Público da Economia, v. n. ${ }^{\circ}$ 31, p. 33-55, 2010.

46 RIVERO, L. R.; PERSSON, J. L.; ROMINE, D. C. et al. ob. cit. 
Native creation myths and religious ceremonies" (Winter, 2001). Tobacco was not used for recreational reasons until after the arrival of the explorers from Europe.In the US, smoking has gained the status of cultural icon through the cinema, television and magazine media. Adolescents who observe smoking in the media have a more positive attitude toward tobacco use, and those who identify with celebrities who smoke are more likely to take up smoking (Sargent, 2003).Movie heroes are three-four times more likely to smoke than are people in real life (Sargent et al., 2001; Meyer, 2001).Ethnicity also has an effect in that white adolescents with friends that smoke are more likely to start smoking than Asian Americans, African Americans, Hispanics, and Pacific Islanders (Unger et al., 2001). The authors attribute this finding to the tendency in the latter three groups to prefer conforming to the roles that parents and mainstream adult society prescribe for them and may be less likely to mimic the minority of adolescents who take up smoking.

The many difficult experiences in the implementation of policies met with resistance from the industry led to the creation of FCTC provisions (5.3) and its guidelines, as can be identified in MEJIA et al ${ }^{47}$, in the following terms:

The transnational tobacco industry has followed closely the potential FCTC ratification process in Argentina. $B A T$ hired the Argentinean public relations firm, Basso Dastugue\&Asociados (BD\&A) which specializes in corporate image and communications.Jorge Basso Dastugue was a NoblezaPiccardo executive in charge of the Public Relations area of BAT.As part of that involvement $B D \& A$ generated a detailed report to NoblezaPiccardo and BAT about newspapers articles regarding the FCTC.Tobacco industry representatives also held frequent meetings with national Deputies requesting not to ratify the FCTC because of supposed economic losses.

\section{According to the guidelines approved by the COP in FCTC article5, numeral 3 , the fact that there is a fundamental and irreconcilable}

47 Cf. MEJIA, R.; SCHOJ, V.; BARNOYA, J.; FLORES, M. L.; PÉREZ-STABLE, E. J. Tobacco industry strategies to obstruct the FCTC in Argentina.CVD Prevention and Control, v. 3, n. 4, p. 173-179. doi: 10.1016/j.cvdpc.2008.09.002, 2008, accessed on April 6th 2012. 
conflict between the interests of the tobacco industry and the interests of the public health policy, has been defined as a guiding principle. Specifically due to the fact that the tobacco industry promotes and produces a product that is scientifically proven to cause addiction, disease and death, and that it gives rise to a variety of social problems, which include aggravating poverty.

As a consequence of this, the states must, according to the guideline, protect the formulation and implementation of public health policies for tobacco control within the tobacco industry, to the greatest possible extent.

There is a focus on the transparency of relations between the tobacco industry and the state. Thus, the Parties must ensure that any interaction with the tobacco industry on issues related to tobacco control or public health, be one of accountability and transparency, which should also be demanded of those who work within this industry.

According Eros Roberto Grau ${ }^{48}$, the "reality of the economic power has been countered against the idealization of liberty, equality and fraternity."

So, in order for the objectives set in the constitution and in international human rights treaties to be achieved, action in the sense of protecting the individual and society against the excesses of the economic power becomes necessary. For that very reason, the guideline determined that the parties should demand that the tobacco industry and those who work to promote their interests, operate and act in a responsible and transparent manner,and also by demanding that the industry provide all the information necessary for the implementation of these standards.

It was also determined that, due to the lethal nature of their products, special or additional incentives for tobacco companies to get established or to conduct their business, should not be granted. In this way, any preferential treatment given to the tobacco industry would be in conflict with the tobacco control policy.

Within this guideline, there were several recommendations made in order that the state party may deal with the tobacco industry's interference in public health policies, among which the following can be mentioned:

(1)To raise awareness about the addictive and harmful nature of tobacco products and the tobacco industry's interference in tobacco control policies implemented domestically;

(2) To set provisions aimed at limiting interactions with the tobacco industry and to ensure the transparency of the interactions that take place;

48 GRAU, Eros Roberto. A Ordem Econômica na Constituição de 1988. 11 $1^{\text {a }}$ Edição. São Paulo: Malheiros, 2006, p. 22. 
(3) To refuse partnerships and non-binding or non-compulsory agreements with the tobacco industry;

(4) To avoid conflicts of interest on the part of official representatives and government officials;

(5) To demand that the information provided by the tobacco industry be transparent and accurate;

(6) To "de-normalize" and, where possible, to regulate the activities described by the tobacco industry as "socially responsible," including but not limited to activities described as "Corporate Social Responsibility."

(7) To not give preferential treatment to the tobacco industry.

There is still a list of measures that should be built up as public policy, adopted in order to control the actions of the tobacco industry, aimed at increasing awareness on the addictive and harmful nature of tobacco products and the tobacco industry's interference in the Parties' tobacco control policies;

In addition to that, there is the need to draw the attention of all sectors of government and the population to inform them and make them aware of the interference, past and present, of the tobacco industry in the definition and implementation of public health policies for tobacco control.

There is also express prohibition, within the guideline in FCTC article 5, numeral 3, for all parties to accept, support or endorse that the tobacco industry, organize, promote, participate or take any initiatives aimed at young audiences, for public education and other initiatives that relate directly or indirectly to tobacco control. In additionto not being acceptable for states to receive assistance or legislation proposals for tobacco control or policy made, by or in collaboration with the tobacco industry.

There is also a list of recommendations in order to avoid possible conflicts of interest on the part of official representatives and government officials.

Thus, questions may arise as to the possible violation of the principle of free enterprise, engraved in article 170 of the Federal Constitution as one of the fundamentals of the Brazilian economic order, by the provisions set in the directive, as, apparently, it would cause difficulties for the tobacco industry.

However, this contradiction is only apparent, and free enterprise is not violated either by the guideline or by the provision of the FCTC, as it guarantees freedom of enterprise, while not inducing the ability to be enterprising, and it does not require constant action directed at stimulating any productive activity. It is, therefore, possible to discourage activities that are harmful to public health.

It shouldn't be inferred that the market is open for people who want to invest and produce whatever they want. In fact, such freedom 
does not exist.

It can be argued that the private economic initiative must be understood exactly in the form of a subjective right that guarantees the individual the possibility of organizing and exercising any mode of economic activity aimed at obtaining a return of capital, while it being necessary to remember that there isn't total freedom for economic exploitation.

This is limited by other constitutional principles. The protection of health and the environment, as well as social justice, may be taken as such limiters.

What is observed is that there should be a regulatory activity by the state, as described above. And the regulation by the state has the function of controlling and balancing economic agents operating within certain economic activities, which is done by the limitation of certain practices and the total inhibition of others.

According to CalixtoSalomãoFilho" $0^{49}$ : "Disparate when subjected to the logic of the market, these principles can be reconciled by coherent regulation."

On free enterprise, according Eros $\mathrm{Grau}^{50}$, it is noteworthy that it has numerous meanings which can be envisioned within the principle, that it is two-sided, and it can be understood as the freedom of commerce and industry and as the freedom to compete. He goes on to affirm that

"Coupling this classification criteria onto another, leads to the distinction between public freedom and private freedom, we may equate the following chart of exposure of such senses:

Freedom of trade and industry (non-interference by the state in the economic domain):

a.1) the faculty to create and operate an economic activity in a private capacity - public freedom;

a.2) non-subjection to any state restriction, except by virtue of the law - public freedom;

b) Freedom to compete:

b.1) the faculty to win over customers provided it is not by means of unfair competition - private freedom;

49 SALOMAO FILHO, C. . Regulação da atividade econômica. 1. ed. São Paulo: Malheiros, 2001, p. 30.

50 GRAU, Eros Roberto. A Ordem Econômica na Constituição de 1988. 11ª Edição. São Paulo: Malheiros, 2006, p.204. 
b.2) a ban on forms of action that would deter the competition - private freedom;

b.3) the neutrality of the state before the competitive phenomenon, in equality of conditions of competition - public freedom.

In this manner, the action of the state with regards to organizing, regulating and controlling economic activity, must seek a constitutional basis for limiting free enterprise. Therefore, it is the Constitution which may set the limits, as it is the Constitution which brings the guarantees. It also concluded that the limitation brought by the constitution requires regulation. In other words, health, having been constitutionally guaranteed, must pass through a regulation that gives it leverage, which is what ANVISA did, in the case of the ban on cigarette flavour additives, as a measure to encourage and promote health.

The Constitutional Court of Colombia leaned on the same topic, on October 20th, 2010, in Sentence C-830/10, Expedient D-809651. To the Court, the tobacco sector is a liability market, and it should not be encouraged by the state ${ }^{52}$, but merely tolerated in view of the implications it brings about, especially in relation to public health.

There isn't, therefore, an incompatibility between the guideline in FCTC article 5, numeral 3, and the principle of free enterprise, essentially, through it is possible, in principle, to put a limit to it. Moreover, transparency is already guaranteed in article 37 of the Constitution, as well as the protection of health.

\section{Conclusion}

The advances in International law, driven by a deepening in international relations based on technological advancement, encourages a deeper dialogue between domestic decisions and international guidelines. There is an increase in issues involving joint action by several states, which leads to the internationalization of law, which, in short, means the transfer of issues to international law that were previously restricted to the domestic order.

One of the issues that underwent this internationalization is the

51 Decision taken in a class action brought by J. Pablo Corrales Caceres, a Colombian citizen, the entire content of which can be accessed at http://www.secretariasenado.gov.co/senado/ basedoc/cc_sc_nf/2010/c-830_1910.html

52 CABRERA, Oscar A. \& GOSTIN, Lawrence O. Human rights and the Framework Convention on Tobacco Control:mutually reinforcing systems.In:International Journal of Law in Context, 7,3 pp.285-303 (2011) Cambridge University Press. 
one related to tobacco control, object of the first international treaty on public health, the Framework Convention on Tobacco Control, which is embodied in the parliamentary diplomacy of the World Health Organization; given the imperative of creating uniform public policies for tobacco control and the control of the action of the tobacco industry, as the results can be more effective.

In addition to the standards of the actual text of the treaty, the COP creates guidelines for better implementation of international standards. In this way, the states must not ignore the FCTC in the implementation of domestic standards for tobacco control. They should also follow the guidelines as a result of the authentic interpretation of the treaty.

The guidelines set out in the Conference of the Parties (COP) can be equated to the acts generated by the regulatory or normative power of public administration. Therefore, there is an international administrative law, which would serve as the basis for demonstrating the binding force of the guidelines, as well as the existence of autonomous interpretation of the international treaty, as held by the parties themselves.

These are some of the many consequences brought about by the ratification of the FCTC, which cannot be neglected as a component of the standards that serve as the interpretation according to the Constitution. Therefore, the guidelines are binding for the FCTC parties as much for an exercise of the regulation as by an expression of its authentic interpretation.

Domestically, under the penalty of omission and international accountability, the state must, in dialogue with the FCTC and the guidelines, determine the regulation of the product and its use, which in Brazil, is attributed to ANVISA.

Keeping in mind that the protection brought by the FCTC, clearly outlined at the convention, is a minimum parameter, the states may set up mechanisms and policies to improve the protection.

In Brazil, ANVISA can and should regulate the product, exactly as defined within the law that created it. To that end, the guideline in article 5, numeral 3, created by the COP, is essential as it refers to transparency and control of economic power.

Highlighting the fact that there is no incompatibility between this guideline and article 170 of the Federal Constitution, due to the fact of there being no absolute principle, the principle of free enterprise is no exception. Furthermore, the actions of the tobacco industry are not curtailed by the guideline, and there should be, however, transparency in their actions, which is already established in the Constitution of Brazil, article 37 . The protection of health is also the basis for a regulation aimed at the conventional guideline.

With regards to Brazil, the implementation of the directive has, therefore, constitutional protection, in addition to allowing more 
effective control of economic power, which, also under the constitution, cannot be exercised in an abusive manner, in accordance to article 173, paragraph 4, of the Federal Constitution.

Therefore, regulation is necessary and should be performed domestically, based on the guidelines and on the treaty, which removes the violation of constitutional principles of the economic law, the main example of which being free initiative, which is also seen as a foundation of the Brazilian economy. As an example of an important decision on the issue, making concrete the possibility of domestic regulation in line with the international template, there is the stance assumed by the Court in Colombia in the action brought forth by Pablo J. Caceres Corrales.

\section{REFERENCES}

ACCIOLY, Hildebrando; NASCIMENTO E SILVA, Geraldo Eulálio do. Manual de Direito Internacional Público. $19^{\mathrm{a}}$ ed. CASELLA, Paulo Borba, atualizador. São Paulo: Saraiva, 2008.

ARAUjO, E. N. Curso de Direito Administrativo. $3^{\mathrm{a}}$. ed. São Paulo: Editora Saraiva, 2007.

BANDEIRA DE MELLO, Celso Antonio. Curso de Direito Administrativo. 15a . ed. São Paulo: Malheiros, 2003.

CABRERA, Oscar A. \&GOSTIN, Lawrence O. Human rights and the Framework Convention on Tobacco Control: mutually reinforcing systems. In: International Journal of Law in Context, 7,3 pp. 285-303 (2011) Cambridge University Press.

CARVALHO FILHO, José dos Santos. Manual de direito administrativo. $24^{\mathrm{a}}$ ed. Rio de Janeiro: Lumen Juris Editora, 2009.

CARVALHO RAMOS, André. O Diálogo das Cortes: O Supremo Tribunal Federal e a Corte Interamericana de Direitos Humanos. In: AMARAL JÚNIOR, Alberto do; JUBILUT, Liliana Lyra. (Org.) $O$ STF e o Direito Internacional dos Direitos Humanos. São Paulo: QuartierLatin, 2009, p. 805-850.

COELHO, Paulo Magalhães da Costa. Manual de Direito Administrativo. São Paulo: Saraiva, 2004.

CONFORTI, Benedetto. Diritto Internazionale. $8^{\text {a }}$. Edizione. Napoli: EditorialeScientifica, 2010.

DI PIETRO, Maria Sylvia Zanella. Direito Administrativo. 21ª ed. São Paulo: Editora Atlas, 2008.

GILMORE, A.; NOLTE, E.; MCKEE, M.; COLLIN, J. Continuing influence of tobacco industry in Germany.The Lancet, v. 360, n. 9341, 
p. 1255. doi: 10.1016/S0140-6736(02)11262-1, 2002.

GRAU, Eros Roberto. A Ordem Econômica na Constituição de 1988. $11^{\text {a }}$ Edição. São Paulo: Malheiros, 2006.

HAMMOND, R.; ASSUNTA, M. The Framework Convention on Tobacco Control: Promising Start, Uncertain Future. TobaccoControl, v. 12, n. 3, p. 241-242. doi: 10.1136/tc.12.3.241, 2003.

MEIRELLES, R. H. S. A ratificação da Convenção-Quadro para o Controle do Tabaco pelo Brasil: uma questão de saúde pública. Jornal Brasileiro de Pneumologia, v. 32, n. 1, p. 0-0. doi: 10.1590/S1806$37132006000100002,2006$.

MEJIA, R.; SCHOJ, V.; BARNOYA, J.; FLORES, M. L.; PÉREZSTABLE, E. J. Tobacco industry strategies to obstruct the FCTC in Argentina.CVD Prevention and Control, v. 3, n. 4, p. 173-179. doi: 10.1016/j.cvdpc.2008.09.002, 2008.

MOTTA, Paulo Roberto Ferreira. Agências reguladoras. Barueri, SP: Manole, 2003.

REICH, Robert. Supercapitalismo. Rio de Janeiro: Ed. Campus; 2008.

REZEK, José Francisco. Direito Internacional Público - Curso Elementar. 13 .ed. São Paulo: Saraiva, 2011.

RIVERO, L. R.; PERSSON, J. L.; ROMINE, D. C. et al. Towards the world-wide ban of indoor cigarette smoking in public places. International Journal of Hygiene and Environmental Health, v. 209, n. 1, p. 1-14. doi: 10.1016/j.ijheh.2005.07.003, 2006.

SALOMÃO FILHO, C. Regulação da atividade econômica. São Paulo: Malheiros, 2001.

SHAW, Malcolm N. Direito Internacional. São Paulo: Martins Fontes, 2011.

SOARES, Guido Fernando Silva. Curso de Direito Internacional Público. 2. ed. São Paulo: Editora Atlas, 2004.

STEWART, R. B.; SANCHEZ BADIN, M. R. The World Trade Organization: Multiple Dimensions of Global Administrative Law. International Journal of Constitutional Law, v. 9, n. 3-4, p. 556-586. doi: 10.1093/icon/mor051, 2011.

SUNDFELD, Carlos Ari. Introdução às Agências Reguladoras. In SUNDFELD, Carlos Ari (Org.) .DireitoAdministrativoEconômico. São Paulo: Malheiros, 2006.

TAYLOR, ALLYN L., A. L.; ROEMER, RUTH, R.; LARIVIERE, JEAN, J. Origins of the WHO Framework Convention on Tobacco 
Control. SSRN eLibrary.Retrieved May 20, 2010, from http://papers. ssrn.com/sol3/papers.cfm?abstract_id=818984, 2005.

TAYLOR, Allyn L.; ROEMER, Ruth; LARIVIERE, Jean.Origins of the WHO Framework Convention on Tobacco Control.American Journal of Public Health, v. 95, No. 6, p. 936-938, June 2005; U of Maryland Legal Studies Research Paper No. 2005-50. Disponível em SSRN: $<$ http://ssrn.com/abstract $=818984>$.

VEDOVATO, Luís Renato . A Convenção Quadro sobre Controle do Uso do Tabaco. In: Clarissa Menezes Homsi. (Org.). Controle do Tabaco e o Ordenamento Jurídico Brasileiro. Rio de Janeiro: LUMEN JURIS EDITORA, 2011, v. 1, p. 3-31.

VERDIER, P.-H.Transnational Regulatory Networks and Their Limits. Yale Journal of International Law, v. 34, p. 113-172, 2009.

WHO Report on the Global Tobacco Epidemic, 2008: The MPOWER package.

YACH, D.From Framingham to the Framework Convention on Tobacco Control. Progress in Cardiovascular Diseases, v. 53, n. 1, p. 52-54. doi: 10.1016/j.pcad.2010.05.001, 2010. 